\title{
UMA LEITURA (E ESCRITA) QUE NOS MOVE: COSTURANDO POSSIBILIDADES ENTRE EDUCAÇÃO E A LITERATURA DE MIA COUTO
}

\author{
READING (AND WRITING) THAT MOVES US: SEWING \\ POSSIBILITIES AMONG EDUCATION AND MIA COUTO'S \\ LITERATURE
}

\section{UNA LECTURA (Y ESCRITURA) QUE NOS MUEVE: COSIENDO POSIBILIDADES ENTRE EDUCACIÓN Y LA LITERATURA DE MIA COUTO}

\begin{abstract}
Alice Copetti Dalmaso*
Membro do Grupo de Estudos e Pesquisas em Arte, Educação e Cultura da Universidade Federal de Santa Maria; desenvolve pesquisa na área de Educação, com ênfase nas temáticas de produção de subjetividades na contemporaneidade, formação e filosofia da diferença Marilda Oliveira de Oliveira**

Professora da Universidade Federal de Santa Maria; Membro da International Society for Education through Art InSEA
\end{abstract}

Resumo: Exploramos as linhas deste artigo ao nosso modo de responder "O que é ler?", “O que é ler Mia Couto?” Aventura da leitura que dispare o desejo de escrever: movimento de encontrar na materialidade literária a promoção da ação da escrita, traçando possibilidades de pensar a formação em educação em consonância com esse movimento. A partir de contribuições de autores, como Barthes, Deleuze, Larrosa (entre outras vozes), temos produzido o que, nestes escritos, nomeamos como experimentações: relações de escritas, de produção de pensamento, a partir e com a leitura de alguns escritos do escritor Mia Couto. Experimentar como essa literatura nos movimenta a mapear possibilidades de produzir experiência com a leitura e a escrita, de criar espaços e tempos de liberdade e de não embrutecimento.

Palavras-chave: Leitura e escrita. Literatura. Formação. Pesquisa em educação. Mia Couto.

\footnotetext{
"Mestre em Educação pela Universidade Federal de Santa Maria; Doutoranda em Educação na Universidade Federal de Santa Maria.

** Doutora em História, Geografia e História da Arte pela Universidad de Barcelona; Mestre em Antropologia Social pela Universidad de Barcelona.
} 
Abstract: We explore the lines in this article as our way to answer "What is reading?", "What is to read Mia Couto?". Reading adventure that triggers the desire for writing: movement of finding in literary materiality the promotion of action in writing, tracing possibilities for thinking the formation in Education in consonance with this movement. By means of contributions from authors such as Barthes, Deleuze, Larrosa (among other voices), we have produced what is labelled in these writings as experimentations: relations between our writings, thought production through and with the reading of some writings from Mia Couto. To experiment this literature allows us to map possibilities for producing experience with reading and writing, for creating space and time of freedom and non-brutalization.

Keywords: Reading and writing. Literature. Formation. Research in education. Mia Couto.

Resumen: Exploramos las líneas de este artículo a nuestro modo de contestar "Qué es leer?", "Qué es leer Mia Couto?" Aventura de lectura que dispare el deseo de escribir: movimiento de encontrar en la materialidad literaria la promoción de la acción de la escrita, demarcando posibilidades de pensar la formación en educación en consonancia con ese movimiento. Con aportes de autores como Barthes, Deleuze, Larrosa (entre otras voces), hemos producido lo que, en estos escritos, nombramos como experimentaciones: relaciones de escrituras, de producción de pensamiento, a partir y con la lectura de algunos de los textos del escritor Mia Couto. Experimentar como esa literatura nos mueve a demarcar posibilidades de producir experiencia con la lectura y la escritura, de crear espacios y tiempos de libertad y de no embrutecimiento.

Palabras clave: Lectura y escritura. Literatura. Formación. Investigación en educación. Mia Couto.

\section{INTRODUÇÃO}

Palavras, sentidos que contemplem algumas das passagens de relações estabelecidas com uma escrita literária. A escrita que nos move, e que se faz junto ao conceito de leitura que procuramos aqui trazer, produz-se numa névoa de intenção que persiste entre os cruzamentos da vida: o de desaprender um pouco sobre nós mesmos, de destruirmos coisas que não querem ser dadas como nossas, mas que se mantêm encrustadas em nossa pele tal como uma segunda pele: imperceptível, se olhada com descuido.

Talvez por isso insistimos num aporte de pensamento que inicie a leitura de um texto (ou de qualquer outra coisa com a qual nos encontramos) que não o/a 
interprete, mas que o/a experimente. Tomando como experimentação, abrimos mão do ímpeto de conclusões, arriscando-nos, assim, a um exercício de escrita que esteja em falta com alguém ou alguma coisa, uma proposta ou especificamente um ideal de um texto. Essa escrita, aqui acompanhada das noções de literatura, leitura, devir, procura conjugar com a formação e a educação, onde movimentos dessa experimentação não se esgotem, criando entradas e saídas para outras conexões.

Leitura e literatura partem juntas nessa travessia incerta. Tomando a leitura como experimentação, temos a literatura como algo que nos ensina, como um espaço e tempo de aprender, que nos oferece uma experimentação sem verdade. Sendo ela mesma uma força que problematiza, tira-nos de uma lógica de inteligibilidade do que se lê, apaga a escritura num logos, e nos faz inventar contiguidades múltiplas e caminhos de sentidos sempre diversificados, sempre em devir. Com ela, não intencionamos representar, designar um "ser do texto", uma unidade da palavra fechada em si mesma, mas em inventar realidades, à guisa de uma não dominação de uma forma linguística.

Diluímos-nos com a literatura, ao aprender com ela, ao cedermos com vontade às solicitações que ela faz, de pensar junto ao que se lê (BARTHES, 2012), ao dar espaço, abertura e presença aos seus signos. Jogar e representar com um texto: infinitos modos de negociar com ele, nascendo e sendo outros no espaço que ele nos dá e, quem sabe, nos descobrirmos música, bicho, mulher, criança... entre uns e outros.

\section{DO LER...}

"Nunca lhe aconteceu, ao ler um livro, interromper com frequência a leitura, não por desinteresse, mas, ao contrário, por afluxo de ideias, excitações, associações? Numa palavra, nunca lhe aconteceu ler levantando a cabeça?” (BARTHES, 2012, p. 26). Ler que nos escapam as folhas nos gestos de tê-las nas mãos, de um cheiro novo que saltam delas; de um tempo que soergue as palavras, de não encontrá-las nem entendê-las, quando nos pomos em tatear o que desconhecemos. Quando nos arrastamos ao desconhecer o que ali está, mas que ainda assim lemos. Quando mesmo cansados e entediados, persistimos no mundo do livro que adentramos sem poder sair até terminá-lo, ainda que não tenha fim, ainda que um livro não seja a leitura que fazemos dele. Jogatina de visões, disparo de mundos, composições infinitas, ao fazer dele nascimento de alguma coisa, (trans)formação, saída de formas.

O caráter de um livro que consegue explorar certa violência, gerando efeitos de abalo, tomado como experiência limite, marginal, que nos desloca de uma postura cômoda em lê-lo, arrastando-nos para lugares impensados. Um texto de fruição, 
de disfrute, é esse que nos sacode, que nos divide, produz espaços para que joguemos com ele, que nos pluraliza, despersonalizando-nos, pondo-nos em movimento, algo novo em sensação, em devir. Esse texto que, num desacordo aceito de nos fazer levantar a cabeça quando lê e, ainda assim, de voltar a ele de uma maneira um tanto encantada, é o movimento que Barthes toma como uma leitura de fruição: algo que um texto (e uma escrita) pode ter de suficientemente legível ao leitor, para que estes efeitos de abalos possam ser gerados no leitor (BARTHES, 2008, 2012).

Riscos de uma leitura. Perigo de uma aventura? Como leitores da literatura que aqui traremos, procuramos operar num modo em que, pelas palavras de Blanchot, não tomamos o texto como uma

[...] realidade definida e segura, nem mesmo como um modo de atividade precisa: ela é antes aquilo que não se descobre, não se verifica e não se justifica jamais diretamente, aquilo de que só nos aproximamos desviando-nos, que só se capta indo para além dela [...] (BLANCHOT, 2005, p. 293).

Porque não há uma essência da literatura e não buscamos por ela - posto que isso nos escapa -, talvez na intenção de um processo de fazer com que a composição de um livro só nos tome como efeito da própria afirmação da obra, das palavras, do vapor das mesmas, independente de forma, gêneros, do lugar que se escreve.

Nessa leitura, onde tudo nos escapa, onde tudo está aquém e além da literatura, é que apostamos. Desejamos a própria experiência da força que a palavra poética possui de destituir o lugar do pensamento determinado pela razão, e que suporta o vago, o espaço, os lugares infinitos, a ambiguidade dos sentidos. Essa experiência própria da literatura, de dispersão, de "aproximação do que escapa à unidade, experiência do que é sem entendimento, sem acordo, sem direito - o erro e o fora, o inacessível e o irregular" (BLANCHOT, 2005, p. 300), é o que nos interessa e nos move a pensar a formação e a educação.

\section{3 ... E DO ESCREVER, LENDO}

Escreve-se lendo, sobre uma mesa cheia de livros. E entre ler e escrever, às vezes, acontece algo, acontece algo conosco. Talvez isso que chamamos de "pensar" seja a experiência desse "entre". (LARROSA, 2014, p. 139).

Liberar o desejo de uma escrita que se produz com a leitura, onde encontramos nas materialidades literárias a promoção da ação da escrita. Pensar uma pesquisa em educação em consonância com esse movimento, sem direções exatas, lugares 
de chegadas, conclusões. Desconfigurar e amontoar ideias, desvincular-se de certa normatividade e mitos de uma escrita, de uma pesquisa acadêmica, de verdades em educação. Uma escrita que não se faça em mensagens: reunimos aqui apenas desejos, expressões, locuções com investimentos (e desinvestimentos) de si, na desmontagem e agenciamentos de outras linguagens. Inventamos espaços de escrita, possibilidades de vida com ela. Vagueamos entre isso tudo, para sermos outros em educação.

Uma aventura da leitura': aquela que dispara também o desejo de escrever. Que do espaço permitido para que o leitor nasça, o desejo da escrita surja. Não escrever como o autor, mas propriamente o desejo que o escritor teve de escrever. Estes movimentos que se intercambiam é o que aqui justamente são abordados: uma leitura que nos suscita outra escritura, e por sua vez outras leituras, que nos forçam a pensar, nos ensinam algo de incorporal, de indecifrável, a ponto de gerar novamente uma escrita: uma escrita que se constitui ela mesma como processo formativo. Leituras carregadas de um suplemento de sentidos e que exigem um trabalho, um trato com o que se produz no corpo-pensamento: "ler é fazer nosso corpo trabalhar [...] ao apelo dos signos do texto, de todas as linguagens que o atravessam e que formam como que a profundeza achamalotada das frases." (BARTHES, 2012, p. 29).

Procuramos nos movimentar sem buscar qualquer verdadeiro sentido de um texto filosófico ou texto literário - prática de dizer o que já foi dito, costumeiramente praticado pela erudição universitária - e operarmos numa busca livre das potencialidades de significação aprisionadas num texto (MARTON, 2009). Ou seja, trata-se de usar as vozes que intercruzamos inventando um diálogo entre pensadores, usando seus escritos e conceitos como instrumentos, deformando-os, construindo outras linhas, fazendo tencionar com aquilo que pudermos e desejarmos, dentro dessa leitura afetiva, onde propriamente colocamos o texto num porvir.

Quando, assim, é possível libertar a leitura, num mesmo movimento, libertamos a escritura, e libertamos o fazer-se o centro do processo de palavra, afetando a escritura e afetando-se a si próprio, fazendo coincidir, afinal, ação e afeto, afecção-escrita (BARTHES, 2012). Como para Deleuze (1988-1989), atiçamos o corpo num modo que uma escrita que se torne ela mesma devir, aproximando-nos de certa animalidade: um estar à espreita, um observar sem ser visto, numa atenção flutuante que está sempre à espera de uma oportunidade, de captar algo que dê novos sentidos ao mundo, que o transforme, que o desterritorialize. Estar à espreita, de forma que nunca estamos tranquilos: sempre em perigo, lemos e escrevemos numa aventura-devir-animal.

Limitamo-nos aqui a poucos ensaios tomados como experimentações: produções de escritas no interior uma escrita, jogo, conversas de nossas escritas a partir e 
com a leitura de fragmentos de contos do livro O Fio das missangas (2009), do escritor moçambicano Mia Couto. Nesse encontro, produzimo-nos com o texto, transformamos ele e nos metamorfoseamos juntos. A escrita, como gesto de inscrição, lança-nos na produção de escritos que não intentam ensinar algo, pedagogizar, mas aprender, no próprio ato de escrita e leitura. Seguir as palavras, os encontros, o animado e o inanimado, não para representá-los, mas em busca de suas singularidades, decifrando-as, aprendendo com elas (DELEUZE, 2006). Desconhecer-se num processo contínuo de produção de si mesmo, em outros modos de constituir processos educacionais. Aprender a despistar o que nos disciplina, o que nos coage. E, então, com elaborações de um aprender pela literatura, compartilhamos dessa breve experimentação.

\section{EXPERIMENTAÇÕES ${ }^{2}$}

Nada impede de rir e brincar. Fardos postos em terra, ria-se. Não carregar mais. Livra-se, desfaz-se de seus pesos e abutres de dor. Fazer a vida leve demanda coragem. À vontade, gozo de rir-se, rindo-se toda, eleva o seu mais alto grau de potência. Questão de saúde, de vida, de cura (DELEUZE, 1997). Essas palavras que se põe a vibrar, numa linguagem afetiva, intensiva, que treme em nós. Quando todo suspense em cenário nos coloca em articulação com personagens, com um retrato no chão, os cacos de vidro, com o sangue de sua barriga, dos lençóis, ou quando ela ri sozinha na cama, em corpo-alívio.

Tumba, retumba. Acompanhamos as batidas de uma escrita que se faz em sopros, como se sussurrasse, em frases curtas. Crianceiras, delírios. Rajadas de vento. Uma brisa.

\footnotetext{
Estou tão feliz que nem rio. Deito-me com desleixo, bastando-me: eu e eu. O regressar de meu marido mediu, até hoje, todas as minhas esperas. O perdoar a meu homem foi medida do desespero. Durante tempos, só tive piedade de mim. Hoje não, eu me desmesuro, pronta a crianceiras e desatinos. Minha alegria, assim tanta, só pode ser errada.

Desculpe-me, Cristo: esplendoroso é o que sucede, não o que se espera. E eu, durante anos, tive vergonha da alegria. Estar-se contente ainda vá. Que isso é passageiro. Mas ser-se alegre é excessivo como pecado mortalício. (COUTO, 2009, p. 69).
}

Reexistir em tremedeiras do peito que se esguia pelas culpas de ser mulher. Pequenezas que de nada implantam significados: como se ser mulher já fosse todo fardo que carregássemos. Nós consumamos nossos dias, brincamos com nossas criações e viajamos em nossos espaços imóveis. Somos sugadas e sugamos, entramos num 
jogo explícito de aceitar os rumores de um Maior, que coage, manda e late. Quantos sobram de nós mesmos como suporte de sermos outros?

É de noite e falta-me apenas um quase para estar sozinha no quarto. Ou, no rigor: o quarto está sozinho comigo. Nesta mesma cama sonhei tantas vezes que o meu amor vinha pela rua, eu escutava seus passos, cheia de ânsia. E antes que ele chegasse, corria a fechar a porta. Fosse esse gesto, o de trancar a fechadura, o meu fingido valimento. Eu fechava a porta para que, depois, o simples abrir dos trincos tivesse o brilho de um milagre. Para que ele, mais uma vez, casasse comigo. E o mundo se abrisse, casa, cama e sonho.

Durante anos, porém, os passos de meu marido ecoaram como a mais sombria ameaça. Eu queria fechar a porta, mas era por pânico. Meu homem chegava do bar, mais sequioso do que quando fora. Cumpria o fel de seu querer: me vergastava com socos e chutos. No final, quem chorava era ele para que eu sentisse pena de suas mágoas. Eu era culpada por suas culpas. Com o tempo, já não me custavam as dores. Somos feitos assim de espaçadas costelas, entremeados de vãos e entrâncias para que o coração seja exposto e ferível. (COUTO, 2009, p. 69)

As horas que nos escorrem se fizeram na observação da palavra que se ri, da não palavra que chora, silencia e grita, escorre e baba, volta trêmula, vomita. Ainda assim, sabemos pouco de nós e dos outros que vez em quando nos observam, nos acham, nos assustam, nos vigiam, nos esquecem, nos traem, nos perdem. Tantos nos perderam em insistências de serem os mesmos.

A semana passada foi quando o rasgão se deu. Venâncio ficou furioso quando descobriu, em estilhaços, a emoldurada fotografia da nossa sala. Era um retrato antigo, parecia estar ali mesmo antes de haver parede. Nele figurava Venâncio, ainda magro e moço, posando na nossa varanda. Pelo olhar se via que sempre fora dono e patrão. Surjo atrás, desfocada, esquecida. Sem pertença nem presença.

Ao ver a moldura quebrada e os vidros ainda espalhados pelo chão, Venâncio me golpeou com inusitada força, pontapés cruzaram o escuro do quatro entre gritos meus:

- Na barriga não, na barriga não!

Depois, quando ele amainou, interrompi-lhe o choro e me soaram serenas e doces as palavras:

- Vê o sangue, Venâncio? Eu estava grávida...

- Grávida, você?! Com uma idade dessas!??

Arrumei umas poucas roupas e fui, a pé, para o posto de socorro. Era manhã, fazia chuva e caía o sol. Algures, por um aí, deveria fantasiar um arco-íris. Mas eu estava cega para fantasias. Meu filho, esse primeiro que haveria de nascer, estava morto dentro de mim. As minhas mãos, ingénuas, ainda amparavam o ventre como se ele continuasse lá, enroscado grão de futuro. Antes que beijasse o chão já eu perdera as luzes e deixara de sentir a chuva no meu corpo. (COUTO, 2009, p. 71). 
Criar, para continuar vivendo. Destruir. Quantas mantas de humano é preciso destruir? Devir não-humano de combate, de luta. Que intensidades é preciso que passe, que se efetive, o quanto é preciso esquecer para que a vida se faça vivível, suportável, movimento? E o que permanece para poder, ainda, destruir?

Ao regressar a casa, faço contas às dores. Por certo, Venâncio me espera para me fazer pagar. Por isso, me demoro na varanda como se esperasse um sinal para entrar. E ali permaneço, cala$\mathrm{da}$, como fazem as mulheres que, de encontro ao tempo, rezam para nunca envelhecerem. (COUTO, 2009, p. 72).

Proliferar em corpo cansado. Vontade eterna de cantar por outro corpo que espera. Enquanto ri, somos tempo por vir em cada margem de nós.

Manufaturamos a vida, enquanto ela mesma nos ensina a costurar os dias. Onde encontramos linhas que se estendem em nossa direção, então sorrimos e beijamos. Beijamos a morte e o riso até perder o som de nossa voz.

Quando entro em casa, os estilhaços do retrato rebrilham no chão da sala. O fotografado olhar de Venâncio pousa sobre mim, assegurando os seus direitos de proprietário. Distraída, a minha mão recolhe um vidro. Na cama de casal, meu marido está enroscado, em fundo sono. Deito-me a seu lado e revejo a minha vida. Se errei, foi Deus que pecou em mim. eu semeei, sim, mas para decepar. Se recolhi os grãos, foi para os deitar no moinho. Há quem chame isto de amor. Eu chamo a cruel dança do tempo. Nessa dança, quem bate o tambor é a mão da morte. Lição que aprendi: a Vida é tão cheia de luz que, olhar é demasiado e ver é pouco. É por isso que fecham os olhos aos mortos. E é o que faço ao meu marido. Lhe fecho os olhos, agora que o seu sangue se espalha, avermelhando os lençóis. (COUTO, 2009, p. 69-72).

\section{ESTAR ENTRE AS COISAS, DEVIR-OUTRO}

Pensar o devir na/da educação, o devir da (e na) linguagem, na vida, nas linhas que se cruzam, que nos cruzam, que nos tomam, que se perdem (que nos perdem), que enlaçam, prendem, que se faz na escrita, e que nos faz sermos outros, ao deixarmos de sermos o que nos entendemos como sendo. Vir a ser, que nunca chega a ser, constituição nômade e que muda de natureza, que não para de dividir-se infinitamente, e ser outro. Devir do ser como acontecimento, que se dá no encontro, numa conquista permanente: 
[...] não se nasce ser, torna-se um ser em devir; não por opção, como aludimos anteriormente, menos ainda por escolha ou vocação, mas pelo desejo artístico, pela vontade de potência cuja singularidade peculiar consiste em abrir vias aos possíveis do desejo afirmativo, deixar-se afetar, ser afetado pelas forças e não pelas representações, pelo esquecimento ativo e não pela memória das escarificações ou unhadas no coração, memória tatuada como um abscesso da alma. (LINS, 2009, p. 12-13).

Quantos Venâncios matamos por dia para abrir vias aos possíveis? Quantos Venâncios recolhemos em lençóis para que ainda e sempre persista a vida? A morte jogando com a vida, não em oposição, mas em forças que vagueiam entre elas: e no tempo, é onde isso se faz casa. No balanço em varanda, no andar pelas ruas de volta pra casa, nos vidros que nos tomam parte, no deitar-se, na duração de rir-se. Algo que nos brota ao ler: por que nos preza em destruir? O gozo do que inventa, do que faz fugir, do que mata, do que esquece. Vaguear na atmosfera da mulher que fala e que encontra um produzir linhas de fuga, resistência. É possível “estar por dentro, adentrar-se e respirar numa idade que ainda não tenho ou já tive, um corpo que não percebo, um país que não habito, uma língua que não falo?” (SKLIAR, 2014, p. 145). Parece que é isso que nos ensina e incita a escrever: prolongar-se a nós mesmos mas despedaçando-se, perdendo-se, desvanecendo-se, deixando de saber-se e tornando-se irreconhecível. Pensar nossos processos formativos como um modo de existir, simultâneo ao que se faz no encontro com o texto, de ser afetado por ele em modo de nos fazer cavalgar num corpo que não seja o nosso, num vir a ser algo impensado.

Leitura de intensidade, fazendo o livro funcionar com algo: "se não funciona, se nada se passa, pegue outro livro.” (DELEUZE, 2013, p. 16). Não trata de explicar, nem compreender, interpretar, mas deixar que algo se passe, que produza ligação com algo, que esse algo tenha sido usado para seus próprios fins, porque faz ele maquinar com outras coisas, qualquer coisa. Por isso a literatura é quem nos arrasta. Coagidas a pensar, deixamos que estes atravessamentos se façam em nossa própria constituição que devém, de um trato com o experimento com as palavras, onde a invenção se dá. Invenção do quê? De outros mundos, de outros modos de sentir, de escutar, silenciar, de se afetar pelo tempo, de ser tomado pelo encontro, de despistar a representação, a lei, uma moral, de esquecer feridas de uma memória, de burlar um modus operandi de ler, de escrever, ensinar e de aprender, de afirmar o que nos acontece, de produzir pensamento, de produzir vida. De nos dissolvermos no mundo, sairmos das formas, rachar a nós mesmos: um corpo que não investe em viver um interior separado do exterior, mas que "investe e molda as coisas do mundo da mesma maneira que investe seu corpo.” (GIL, 2009, p. 32). 
De nos contagiarmos mais por aquilo que salta e alegra, que vaza e ri, mesmo em meio às nossas dores, ao que nos aprisiona, ao que nos leva e embala para os lugares em que precisamos ocupar, cotidianamente. Colher nossos percursos, nossos erros e escapes. Tirar nossos pesos em horas que escorrem pelo nosso corpo. É do brincar, do rir, do se esquecer, dos nossos mapas sendo feitos a cada dia, em cada encosta, em cada onda, em cada sombra que nos abraça. Porque temos tudo e nem sabemos do que somos capazes. Somos muitos e não nos bastamos. Também sobre isso, somos aprendizes.

Pela força das palavras, deixamos certo pudor de lado, para diminuir a distância entre nós e as coisas do mundo, dando abertura e fluidez a elas, tornando-nos sensível para um além do corpo, e um antes do corpo. Para destituirmo-nos de nossa própria forma. Talvez, desejo de retorno a algo que treme em nossas línguas, que saltem com nossos corpos no pulo da palavra, conjugarmos instâncias de materialidade com nossa imaterialidade. Liquefazer-se, soterrarmos certezas e valências de um plano de civilidades, de construções de homem, de educação, de formação. Para onde vamos? Interessa, quando somos atravessados, atravessamentos e travessias?

A fabulação da literatura que constrói gigantes, que inventa um povo (DELEUZE, 1997), que nos faz tremer ao tornar as afecções em afetos (DELEUZE; GUATTARI, 1992). Ler, falar, escrever, cantar palavras e sons que ressonam no peito a sensação de que outrora nunca as escrevemos, falamos, ouvimos e sentimos. Palavras que se transversalizam em nós, soerguendo os outros que são sentidos, vividos, pensados com o que se lê. São vias de aprender com uma escrita que faz nascer, que criam seres de sensação e que conservam neles modos de ser, anterior às nossas experiências e representações de sujeito. Tornamo-nos algo sem nome talvez, no gesto da leitura, num modo de nos afetar que atravessa o vivido, o percebido, a memória. Há suportes de podermos atingir algo inatingível, pensar o impensável, viver o que não pode ser vivido: apostas de formação que sai da forma, de outras vidas em educação.

"Vamos encostando em um idioma do caos, em que tudo ainda está por vir. Uma vida que pode ser ainda todas as vidas, todas as linguagens. Mundo informe e caótico é esse que faz mover a escrita, qualquer que seja o continente, a nação, a língua." (COUTO, 2011). Um pouco sobre experimentar palavra que percorre líquido: tudo que ainda se faz, desfazendo-se. A língua outra que sussurra com os peixes. Uma cauda, um esguio, um debater-se. O que perdemos em nossos modos de pouco inundar-se do que desconhecemos e estranhamos?

Sacolejar por águas como se outrora nunca tivéssemos sentido. Dobrar-se agora num ser-se rio, entre água, peixes, peixe que nos olha: já não somos mais os 
mesmos. Nadar, mergulhar, engolir e cuspir água. Inundações: em mundos pequenos e grandes e de tamanhos infinitos desejamos e podemos morar por um tempo em consistências, para saborearmos as coisas com o gosto de que jamais nos bastaremos. Gotejar com os peixes, se fazer correntes e tornar-se palavra líquida em corpo estranho. Silenciar, para alguma verdade que ali se diz.

Guardar na ponta dos dedos o encantamento pelas coisas que nos chegam. Deslizar com a força incólume de ser alguma coisa transitória de nós mesmos. $\mathrm{E}$, talvez, fazer desses escritos algum ruído, que abrace a imensidão do mundo.

Grudamo-nos em vidas para pensar outros em educação.

Minha sabedoria é ignorar as minhas originais certezas. O que interessa não é a língua materna, mas aquela que falamos mesmo antes de nascer. Por isso, me dei licença de escutar Jossinaldo. E fui saindo de casa, caminhando ao mesmo passo do afamado vizinho, lado com lado. Na rua me olhavam, surpresos. Então eu autorizava a companhia do proscrito, no pleno da via pública? Debaixo dos olhares, nos dirigimos ao parque e parámos junto ao lago.

- Veja como ele vem a correr.

E era a maior verdade. O peixão, na vista do vizinho, se aproximou da berma. Jossinaldo debruçou-se e enlaçou a trela à volta da cauda do animal.

- Vá, pegue na trela para ele lhe ganhar familiaridades.

Com o coração de fora, lá segurei na corda. $\mathrm{O}$ bicho veio à superfície da água e me olhou com os olhos, até me custa escrever, com olhos de gente. E remergulhando me conduziu ele a mim, pela margem. Contornei por inteiro a lagoa para me reencontrar com Jossinaldo.

- Deixe-me despedir dele!

Ajoelhado sobre as águas, o vizinho falou palavras que não eram de língua nenhuma conhecida. Ficou, tenho medo de dizer, conversando com o peixe. Ergueu-se Jossinaldo, lágrima escorrendo, e me apertou as mãos, as duas em duplicado. Não falou, retirou-se em silêncio.

Sou eu agora quem, pela luz das tardes, passeia o peixe no lago. À mesma hora, uma misteriosa força me impele para cumprir aquela missão, para além da razão, por cima de toda a vergonha. E me chegam as palavras do vizinho Jossinaldo, ciciadas no leito em que desfalecia:

- Não existe terra, existem mares que estão vazios.

Dentro de mim, vão nascendo palavras líquidas, num idioma que desconheço e me vai inundando todo inteiro. (COUTO, 2009, p. 97-98). 


\title{
6 AGENCIAR LEITURAS COM EDUCAÇÃO: EXPERIÊNCIA, APRENDIZAGEM
}

\begin{abstract}
A escrita é uma casa que eu visito, mas onde não quero morar.
O que me instiga são as outras línguas e linguagens, sabedorias que ganhamos apenas se de nós mesmos nos soubermos apagar. Da minha língua materna eu aspiro esse momento em que ela se desidioma, convertendo-se num corpo sem mando de estrutura ou de regra. O que quero é esse desmaio gramatical, em que o português perde todos os sentidos. (COUTO, 2011, p. 136).
\end{abstract}

Viajamos de identidade, mudamos de casa e de morada (sempre provisória, flutuante, em devir), apropriadas por outras linguagens e sentidos, desmaiadas de silêncio. Levantamos a cabeça e esperamos que algo se conclua, uma ideia do que se acaba de ler; imagens que insistem em se fazer, no que produziu de não pensado: como nos toca uma leitura de Mia Couto. Procuramos sentidos, e nos faltam palavras. Apenas criamos passagens entre uns e outras: experimentações, relações, conversações, como já afirmamos até aqui. Leitura que produz um certo silêncio, um vaguear de olhares, pede que volte a página, procurando compreendê-la: mas não podemos. Por nos termos esquecido, por termos deixado um "eu que lê" à deriva, apagamo-nos num tempo intensivo e aí, então, é que sentimos como se fôssemos demasiado civilizados, em nossas ânsias de esclarecimento, de compreensão. Demasiado anestesiados em uma identidade.

Mia Couto escreve para familiarizar-se com uma não realidade, com os seres que não são, com pessoas que podem ser leões, rios que são pessoas, memórias de antepassados que não conhece. Seus textos circulam em mostrar o que aprende não somente ao transcrever o que há de verossímil, mas também ao inventar personagens, inventando a si mesmo. Seus textos são marcados por histórias que, em sua maioria, passam-se em território africano, em Moçambique pós-independência, onde então o português se tornou a língua mais falada, imprimindo-se nas marcas da cultura de raiz africana. A guerra civil dentre tribos costuma ser o contexto de diversos personagens que contam histórias como possibilidade de resgate de suas vidas: vidas excluídas e criadoras, que se criam em histórias orais como possibilidade de tocarem e inventarem sua própria realidade. No entanto, pode ser uma escrita potente de cruzar territórios, encostando-se em nossas insistências de resistirmos em meio às guerras cotidianas que diminuem nossa potência em viver.

Exploramos essas linhas ao nosso modo de responder "O que é ler?", "O que é ler Mia Couto?" Suas escritas movem de certa forma a subversão de categorias e conceitos, identidades fixas, conhecendo fronteiras de culturas, línguas e etnias que 
nos obrigam a revisitar palavras, decifrar e inventar sentidos. Pairamos no meio... vagueamos com personagens e seus lamentos, mistérios, sopros de vida, conchavos, medos, desvanecimentos, nascimentos, combinações, devires, individuações com outros seres, outras vidas: uma só. Eles são possibilidades de serem muitos em constituições infinitas de si mesmos.

Há forças nos ambientes descritos por Mia. Forças que nos arrastam para lugares de sentir inabitados, desconhecidos, não tocados, despidos de beleza. Dispara um desejo de nos fazermos mundo, chão, bicho, horas, vivacidade, furor, terra, líquido. Estabelecermos zonas indomesticáveis, criar casa onde não se tem família, com seres que não são, que são tudo, que estão entre um e outro: habitar um ser-se rio, peixe, vento, mulher, e o que quiser, para fugir da condição de nossa própria vida. Inventar realidade e dizer a ela que não está dada, não há verdade a ser revelada, desnudada, percebida. Viver estas forças abreviam insistências de nossas atribuições prévias, em nossos papéis, funções, modos de perceber, de afetar e de sermos afetados pelas coisas. Roçamos pela chamada humanidade com curiosidade e já não com devoção, deixamos de estar enjaulados em nossa própria multiplicidade.

Aprendemos com essa escrita (a de um livro, que coexiste com a nossa), e voltamos nosso olhar, mudamos nossa perspectiva à maneira de percebermos o mundo, interpretar os sentidos do mundo. Não é o autor, nem o livro, mas a multiplicidade de que faz o próprio livro, da alteridade que ele porta e da qual somos afetados, que dispara e faz dançar as coisas, desterritorializando a nós e o mundo.

Um estranhamento no contato com um plural de sentidos que não são aqueles que produziam sentido ao nosso corpo, às nossas relações, aos nossos modos de sentir: já somos outros depois que experimentamos um espaço de liberdade com essa leitura. Como se fôssemos carregados de coisas e significados, cheios, gordos "verdades" que não necessariamente são as que gostaríamos de produzir. Verdades que temos de uma identidade mulher, homem, criança, negro, branco, adulto, natureza, cultura. O que sabemos, como sentimos, como lemos e entendemos frente a uma literatura que parece nos arrastar para lugares desconhecidos, que desperta o desejo de um corpo que vibre sob outras disposições, quando aprendemos das vizinhanças, comunicações, conexões entre os seres e as coisas do mundo?

Como se soubéssemos (sem antecipadamente saber) o que Jossinaldo tem a falar com um peixe, o que o outro sentiu na qualidade de guia, de ter esquecido de sua própria língua quando em conexão com a água, com o animal; que os pensamentos de uma mulher que ri diante da vida e da sua morte cotidiana são os mesmos que os nossos, embora sejamos, pensamos, sentimos, amamos, vivemos - após ter sido produ- 
zido e produzido junto à leitura -, de modo distinto; que suas contradições, errâncias e desejos são compartilhados por nós, ou experimentados como nunca o havíamos até o momento. Não somos, no entanto: nem uma mulher, nem o homem que guia um peixe, dado como louco. "Devo sê-lo para comover-me? Devo ser exatamente o representado? [...] Não, não sou eu. E, contudo, outra vez, poderia sê-lo num instante de seu trajeto, num gesto, num olhar." (SKLIAR, 2014, p. 146). Assim, mesmo que ordinariamente voltemos aos nossos postos e funções, o que vamos degustando com a literatura é um iminente sabor, nunca determinado de antemão, às travessias infinitas que somos postos a experimentar. Produzir outras travessias e habitações com a leitura e com uma escrita torna-se nosso desejo de pensar uma (outra) formação.

O que somos capazes de pensar com o que se lê? O que podemos sentir com o que se lê? O que ele (o texto) pensou sobre nós: deixar o texto, deixar o que se lê, pensar em nós. Mas, para isso, é necessário escutá-lo, é preciso que deixemos as memórias de lado, um "eu" centralizado, para que ouça o que esse texto nos diz, algo de que precisamos escutar. O que nos parece, assim, uma clínica (DELEUZE, 1997), um cuidado consigo, um tempo de deixar pensar-escutar, para poder dizer. Dobramos nosso corpo aos hábitos, e a sensibilidade e a inteligência passam a ordenar outras ideias, novas ideias, novas maneiras de exprimir-se, de pensar, de viver. Acabamos por aprender com esses inventores, poetas do mundo, que parecem trabalhar "o abismo entre o sentimento e a expressão, entre a linguagem muda da emoção e o arbitrário da língua, com os que tentaram fazer escutar o diálogo mudo da alma com ela mesma [...]” (RANCIÈRE, 2011, p. 101).

Aprendemos numa experiência de uma linguagem aberta, uma linguagem que dá espaço para criar outras coisas junto dela, de jogar com as palavras, de sabotá-las, de inventar outras imagens que não as dadas, outros dizeres, outras oralidades. Temos possibilidade de experiência (LARROSA, 2010). Por isso a palavra não se torna sagrada, ao passo que seja ela mesma um modo provisório de tocar e ser tocada pelas coisas. A aventura de ler, já mencionada, pode criar laços no pensar uma aventura de formação, arrastando a imagem de indivíduo-professor/ indivíduo-criança/ indivíduo-adulto para lugares irreconhecíveis, inauditos, imperceptíveis, na tentativa infinita de elevar a potência de sermos outros e nos encontrarmos com estes outros.

Junto a isso, abrimos também possibilidade de uma escrita: podemos fazer outras conexões com o que lemos, tecemos novas linhas, emaranhamos novamente os signos... escrevemos, escrevemos de novo. Essas insistências nossas por um espaço de leitura e de escrita podem produzir silêncios, deixando-se a pretensão de dominar, iluminar, esclarecer, tornar a pedagogizar, dizer tudo que se possa dizer para que es- 
cutem e escrevam mais verdades sobre educação. "Frente à verborreia sistemática dos que sabem" (LARROSA, 2010, p. 75), falando ou escrevendo, tornamo-nos poetas de nós próprios, não cabendo mais impor qualquer verdade e forçar qualquer ação.

Sofrer rearranjos, não ter medo nem vergonha de ser tomado pela multiplicidade de um livro e que põe nossas subjetividades em devires: mudar, tal como a vida, que muda a todo instante. A leitura nos joga nesse oceano, e parece nos exigir um atirar-se com coragem, nessa aventura incerta de uma processualidade formativa, deslizante, imprevisível, "uma viagem no não planejado e não traçado antecipadamente, uma viagem aberta em que pode acontecer qualquer coisa, e na qual não se sabe onde se vai chegar, nem mesmo se vai chegar a algum lugar." (LARROSA, 2010, p. 52-53). Entradas e saídas, idas e vindas no contato com impessoais intocados, de certezas que carregamos de nós próprios pulverizarem-se, dos desmanches de uma identidade de mundo, de etnia, religião, de gostos, de vida, das coisas todas que aprendemos e que tomamos como certo, como bom, bonito, mau, justo. Sistemas de valores transfigurados e que, numa linguagem literária, criamos mundos possíveis, impensados, insanos, profanos, mundos onde inventamos, fabulamos, e tomamos a formação algo inerente à vida e ao sentir.

Barthes, um dos maiores estudiosos sobre processos de escrita e leitura, afirma, em um de seus livros, sobre seu desejo de estudar a escrita em diferentes autores, como um "querer-viver." Abandona o querer-agarrar, fundo de todo dogmatismo e busca uma "suspensão das ordens, leis, cominações, arrogâncias, terrorismos, intimações, exigências, querer-agarrar" (2003, p. 30), para um querer-viver. Contagiamos-nos por isso quando encontramos, na literatura, um outro jeito, tocado por Barthes, de um querer-viver, sem determo-nos em definições de um "agarrar" o outro que lê, não implicando nestes escritos protocolos de leitura e de escrita que convençam, agarrem, que determinem um ensinar sobre como escrever ou ler, ou mesmo ser algo em educação: talvez seja início dessa vitalidade-outra de Barthes.

Querer-viver é sempre um convite, um oferecer sem pedir. Querer-viver que percorre e destece as nuances de um texto literário, aquilo que ele apresenta como um grau de música, de uma força, de tonalidades que mudam, que saltam aos nossos olhos quando o lemos sem saber o que salta, e que, de alguma forma, nos modifica. "Tentar viver segundo as nuances que a literatura me ensina" (BARTHES, 2003, p. 27), que compõe junto ao que está sendo lido. Querer-viver trata um pouco disso. Isso nos põe a escrever, a estudar, a costurar sentidos e não sentidos com a educação, pensando a formação como esses processos educacionais que nos modificam. 
Processos que não têm a finalidade de conduzir a um bem, a uma verdade, a um ideal de humano e de sociedade: "educação e processos educacionais não são bons. E não são maus. São processos de modificação." (CORRÊA; PREVE, 2011, p. 187). Trans(formar) lugares fixos de ensinar e de aprender: formação não prescritiva, não normativa, que não tenda a uma formação que construa e busque um modelo ideal do que é o humano, "ser humano". Apostar, assim como Larrosa (2010, p. 12), num "devir plural e criativo, sem padrão, sem projeto, sem ideia prescritiva de seu itinerário e sem uma ideia normativa, autoritária e excludente de seu resultado [...]" Precisamos para isso, deixar que as coisas se deem no sujeito, na abertura de um porvir, sempre imprevisível e novo, sem expectativas e arrogância de alguém ou algo ser como esperamos, desejamos.

Diante disso é que, não nos contentando em experimentar com Mia Couto, nós compartilhamos. Talvez estejamos construindo, em conjunto com tantos outros, uma possibilidade, dentro do campo da formação (e da pesquisa), de uma lida (um trabalho) com um caráter muito microscópico das nossas rotinas e estruturas mentais, físicas, políticas, éticas, estéticas. Onde estamos aprendendo a mapear possibilidades de produzir experiência com a leitura e a escrita: compartilhamento de experimentações como processos de experimentar espaços de liberdade e de não embrutecimento. Um pouco de artistagem, à medida que não nos contentamos com um mero ofício, e em que desejamos

[...] fazer de todo trabalho um meio de expressão; não se contentar em sentir, mas buscar partilhá-lo. O artista tem necessidade de igualdade, tanto quanto o explicador tem necessidade de desigualdade. E ele esboça, assim, o modelo de uma sociedade razoável, onde mesmo aquilo que é exterior à razão - a matéria, os signos da linguagem - é transpassado pela vontade razoável: a de relatar e de fazer experimentar aos outros aquilo pelo que se é semelhante a eles. (RANCIÉRE, 2011, p. 104).

Seja essa nossa micropolítica, microscopia de um pensar a formação, lançamos hastes e desejamos fazer brotar em nós (e, quem sabe, em leitores possíveis), um outro olhar, outra coisa qualquer: outros de nós em educação.

Notas explicativas

${ }^{1}$ Também encontramos em Blanchot, citando a conceituação de livro de Mallarmé, essa força da obra que é
ela mesma devir, ela mesma uma supressão de sentidos e, por isso, não podendo ser dada, acabada, fechada
em si mesma, unívoca; que corresponde sempre a uma leitura infinita, aberta, em possibilidades de que novos
dados sejam lançados. A leitura é operação, que nos coloca no perigo de não poder dizer em "saber o que é o
livro, nem se ele é, nem se o devir ao qual o livro corresponde, ao mesmo tempo que o constitui por sua su-
pressão infinita, já tem agora um sentido para nós e terá algum dia um sentido" (BLANCHOT, 2005, p. 358). 
${ }^{2}$ Os fragmentos dos contos de Mia Couto encontram-se, neste artigo, conforme formatação da revista, em recuo de $4 \mathrm{~cm}$, em grafia Times New Roman, 10 pt. A referência dos recortes de textos utilizados, no entanto, encontra-se apenas no final da sequência original do conto utilizado.

\section{REFERÊNCIAS}

BARTHES, R. O neutro: anotações de aulas e seminários ministrados no Colègge de France. São Paulo: Martins Fontes, 2003.

BARTHES, R. O prazer do texto. 4. ed. São Paulo: Perspectiva, 2008.

BARTHES, R. O rumor da língua. 3. ed. São Paulo: Editora WMF Martins Fontes, 2012.

BLANCHOT, M. O livro por vir. São Paulo: Martins Fontes, 2005.

CORRÊA, G. C.; PREVE, A. M. H. A educação e a maquinaria escolar: produção de subjetividades, biopolítica e fugas. Revista de Estudos Universitários, Sorocaba, v. 37, n. 2, p. 181-202. 2011. Disponível em: <http://goo.gl/hxvkY5>. Acesso em: 28 fev. 2015.

COUTO, M. O fio das missangas: contos. São Paulo: Companhia das Letras, 2009.

COUTO, M. E se Obama fosse africano? e outras intervenções. São Paulo: Companhia das Letras, 2011.

DELEUZE, G. Conversações. 3. ed. São Paulo: Ed. 34, 2013.

DELEUZE, G. Crítica e Clínica. São Paulo: Ed. 34, 1997.

DELEUZE, G. O Abecedário de Gilles Deleuze. Realização de Pierre-André Boutang, produzido pelas Éditions Montparnasse, Paris. 1988-1989. No Brasil, foi divulgado pela TV Escola, Ministério da Educação. Tradução e Legendas: Raccord [com modificações].

DELEUZE, G. Proust e os signos. São Paulo: Forense Universitária, 2006.

DELEUZE, G.; GUATTARI, F. 1992. O que é filosofia? Rio de Janeiro, Ed 34, 288 p.

GIL, J. Reversão. In: LINS, D. (Coord.). O devir criança do pensamento. Rio de Janeiro: Forense Universitária, 2009. p. 19-33.

LARROSA, J. Pedagogia profana: danças, piruetas e mascaradas. 5. ed. Belo Horizonte: Autêntica, 2010. 
LINS, D. Heráclito ou a invenção do devir. In: LINS, D. (Coord.). O devir criança do pensamento. Rio de Janeiro: Forense Universitária, 2009. p. 1-18.

MARTON, S. Da história da filosofia à filosofia. O devir criança do pensamento. In: LINS, D (Coord.). O devir criança do pensamento. Rio de Janeiro: Forense Universitária, 2009. p. 53-66.

O ABECEDÁRIO DE GILLES DELEUZE. Realização de Pierre-André Boutang, produzido pelas Éditions Montparnasse, Paris. No Brasil, foi divulgado pela TV Escola, Ministério da Educação. Tradução e Legendas: Raccord [com modificações], 1988-1989.

RANCIÈRE, J. O mestre ignorante: cinco lições sobre a emancipação intelectual. Belo Horizonte: Autêntica, 2011.

SKLIAR, C. Desobedecer a linguagem: educar. Belo Horizonte: Autêntica Editora, 2014.

Recebido em 21 de março de 2015 Aceito em 17 de dezembro de 2015

Endereço para correspondência: Avenida Roraima, 1000, Camobi, 97105-900, Santa Maria, Rio Grande do Sul, Brasil; alicedalmaso@gmail.com 